\title{
Simple estimate of the influence of competitive inhibition on PBTK based risk assessment
}

Reffstrup, Trine Klein; Petersen, Annette; Nielsen, Elsa; Jonsdottir, Svava Osk

Publication date:

2014

Document Version

Publisher's PDF, also known as Version of record

Link back to DTU Orbit

Citation (APA):

Reffstrup, T. K., Petersen, A., Nielsen, E., \& Jonsdottir, S. O. (2014). Simple estimate of the influence of competitive inhibition on PBTK based risk assessment. Poster session presented at 50th Congress of the European Societies of Toxicology (EUROTOX), Edinburgh, United Kingdom.

\section{General rights}

Copyright and moral rights for the publications made accessible in the public portal are retained by the authors and/or other copyright owners and it is a condition of accessing publications that users recognise and abide by the legal requirements associated with these rights.

- Users may download and print one copy of any publication from the public portal for the purpose of private study or research.

- You may not further distribute the material or use it for any profit-making activity or commercial gain

- You may freely distribute the URL identifying the publication in the public portal 


\title{
Simple estimate of the influence of competitive inhibition on PBTK based risk assessment
}

\author{
Trine Klein Reffstrup 1), Annette Petersen²), Elsa Nielsen¹), Svava Ósk Jónsdóttir¹)
}

Background: In recent years, increased focus has been on the development of methods for assessing health risks caused by exposure to mixtures of chemicals from food and the environment. It has been recommended by international bodies to consider physiologically based toxicokinetic (PBTK) modelling for higher tier cumulative risk assessment of chemicals. Another important area for the use of PBTK is risk assessment of aggregate exposure via different routes (dietary, dermal, etc.).

Method: The competitive inhibition was examined in a binary PBTK model. As an example simulations for a mixture of the Rand S-enantiomers of the pesticide tebuconazole was examined.

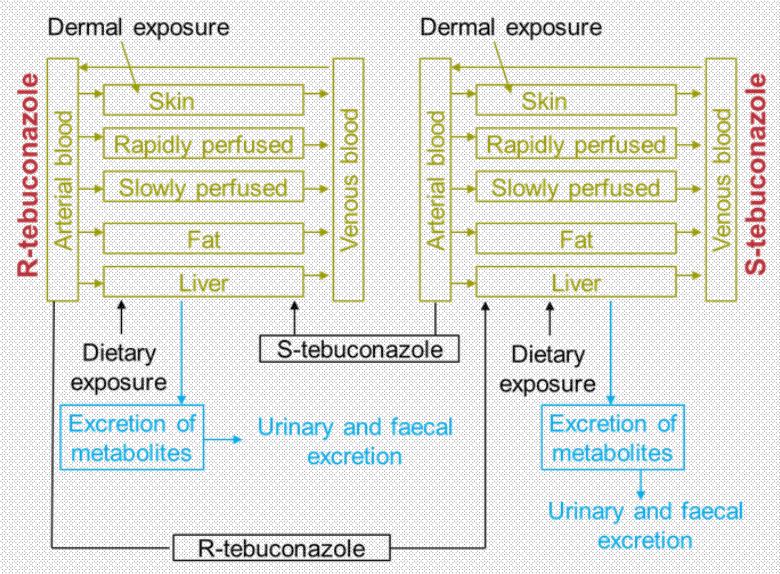

Structure of the model:

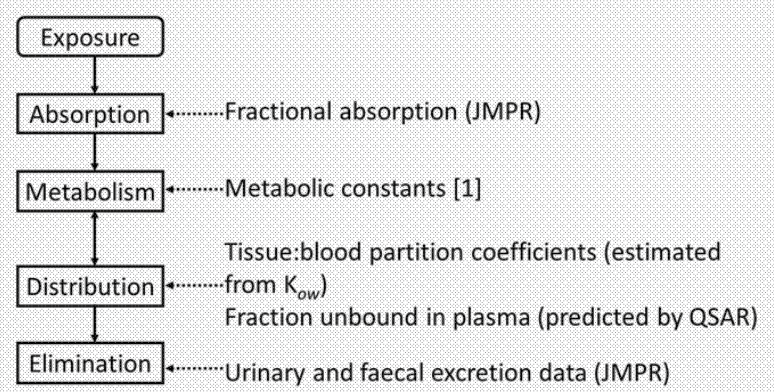

Sources for ADME data used in the development of the PBTK models. Abbreviations: JMPR: Joint FAO/WHO Meeting on Pesticide Residues. QSAR: Quantitative Structure Activity Relationship.

Model validation: Good agreement between experimental and simulated half-lives for R- and S-tebuconazole in rat and rabbit:

\begin{tabular}{|c|c|c|c|}
\hline Species & Experiment, R/S tebuconazole & $T_{1 / 2}(\exp ).[1,2]$ & $\mathrm{T}_{1 / 2}$ (pred.) \\
\hline Rat & In vitro, with inhibition & $36 \mathrm{~min}$ & $50 \mathrm{~min}$. \\
\hline Rabbit & In vivo, with inhibition & $104 \mathrm{~min}$. & $111 \mathrm{~min}$. \\
\hline
\end{tabular}

Results: Simulations made at different single oral doses in rat showed only minimal effect of inhibition at doses up to $1 \mathrm{mg} / \mathrm{kg}$ bw $(0.5 \mathrm{mg} / \mathrm{kg}$ bw of each enantiomer) (graph A). Effect of inhibition was seen after a single oral dose of $10 \mathrm{mg} / \mathrm{kg}$ bw (graph B), but not after corresponding dermal exposure (graph $\mathrm{C}$ ). Internal dose levels were affected by inhibition after $100 \mathrm{mg} / \mathrm{kg}$ bw dermal exposure (graph D).

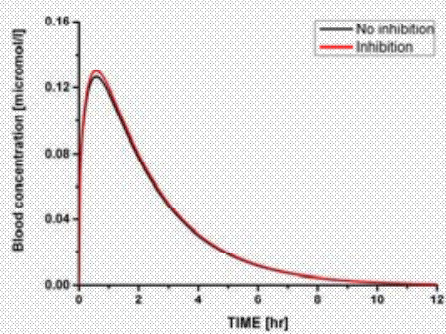

A. Concentration of tebuconazole $(R+S$ form $)$ in rat blood after an oral bolus dose of $1 \mathrm{mg} / \mathrm{kg}$ bw. with and without inhibition considered.

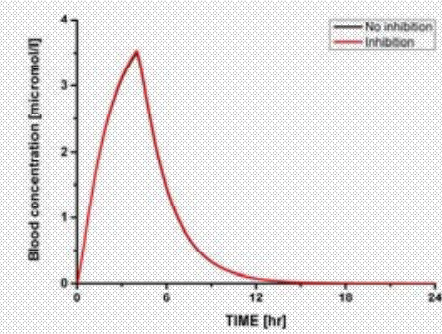

C. Concentration of tebuconazole $(\mathrm{R}+\mathrm{S}$ form) in rat blood after $4 \mathrm{hr}$ dermal exposure of $10 \mathrm{mg} / \mathrm{kg}$ bw with and without inhibition considered.

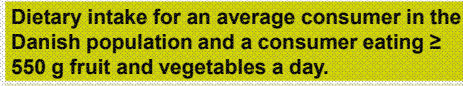
$550 \mathrm{~g}$ fruit and vegetables a day.

$0.013-0.026 \mu \mathrm{g}$ tebuconazole/kg bw/day [3]

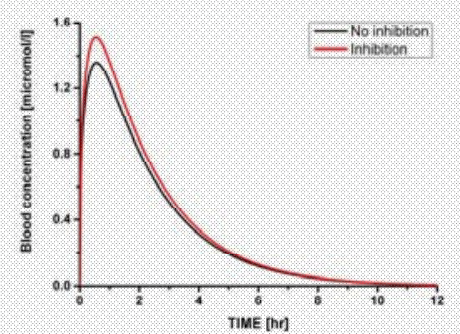

B. Concentration of tebuconazole $(\mathrm{R}+\mathrm{S}$ form $)$ in rat blood after an oral bolus dose of $10 \mathrm{mg} / \mathrm{kg}$ bw with and without inhibition considered

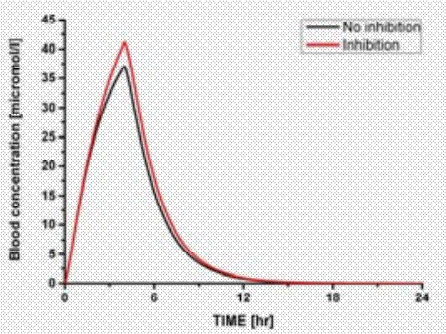

D. Concentration of tebuconazole $(\mathrm{R}+\mathrm{S}$ form $)$ in rat blood after $4 \mathrm{hr}$ dermal exposure of $100 \mathrm{mg} / \mathrm{kg}$ bw, with and without inhibition considered

Estimated occupational exposure by industrial wood treatment, brushing or spraying fields (data from Danish EPA) $4.2-28 \mu \mathrm{g}$ tebuconazole/kg bw/day [4]
Conclusion: The simulations for the two binary mixtures indicate that it is not necessary to include inhibition at realistic exposure levels for humans, i.e. for exposure due to pesticide residues in food and for dermal exposure due to professional use.

Further readings:

http://www2.mst.dk/Udgiv/publications/2014/02/978-87-93178-08-3.pdf 